\title{
Earthquake swarm associated with volcanic eruption, Curaçoa Reef Area, Northern Tonga, July 1973
}

\author{
Earthquake swarm, Curacoa Reef'Area
}

\author{
S. J. Gribowicz - J. H. IntTten - G. K. Suttox $(*)$
}

Received on October $8 t h, 1974$

Sumary. - A submarine voleanic eruption near Curacoa Reef, furst observerl on 12 July 1973 (J.'T.) from Tafalii Island, northern Tongal, was associated with an earthquake swarm in the same area. The swarm began abont $03^{h}$ on 11 . July and died away gradually about $0 \bar{g}^{h}$ on $13 \mathrm{July}$. It comprised 564 events of magnitude $M_{L} \geqslant 3.4$, the largest being of magnitude $M_{L}=5.1$. The swarm area for these comparatively low magnitude earthquakes was abnormally large

The valuation in rate of earthquake oceurrence during the swarm shows two distinct stages, one similar to that in a foreshock sequence, and the other like that in an aftershock sequence, with the latesest events oceurring between the two. The avelage value of $b$, defining the frequency-magnitude relationship, was high: $1.77 \pm 0.15$. Furthermore, this parameter varied during the course of the swarm, a decrease in the $b$ value from 1.8 to 1.1 being followed by a sharp increase to 2.5 after the largest earthquakes and principal volcance cruption.

Values of seismic moment were obtained from $A R$ for 118 anthquakes which were well recorded by long-period seismographs. Other source characteristies were determined from the difference between the logarithm of seismie moment and the local magnitude. The souree sizes were found to be unusually large. There was a time variation of source properties during the swarm. The variation of the displacenent shows an inverse correlation with the variation of the coefficient $b$.

'The swarm produced very distinctive $T$ phases, well recorded at a hydrophone near Wake Island and at seismograph stations situated on the oceanic side of the Tonga Trench: these were not recorded at seismoglaph stations within the island ares.

(*) Geophysics Division, Department of Scientific and Industrial Researeh, Wellington, New Zealand 
Comparison between trace amplitudes of $T$ waves on the Wake Island hydrophone records and magnitudes determined from the body waves shows that nine events introduced anomalously large amounts of energy into the SOFAR layer. These are interpreted as submarine voleanie eruptions.

Riasscxto. - Un cruzione vulcanica sottomarina vicina al Curacoa Roef, fu prima osservata it 12 luglio 1973 ('T.L.) dallisola Tafahi ('Tongat settentrionale) e poi associata ad uno sciame di terremoti avvenuto nella stessa area. Lo sciame obbe inizio l'll luglio verso le ore 3 , per terminare verso le ore 7 del giomo suceessivo. Vi furono 564 eventi di $y_{L} 3.4$; la scossa più forte ebbo una $H_{L}=$ o.l. Larea macrosismiea dello sciame, rispetto alla bassa magnitudo dei terremoti, fu eccessivamente vasta.

La variazone nella ricorrenza dei terremoti durante lo seiame mostra due fasi distinte: ma, simile a quella che si ha in ma sequenza di seosse premonitriei, ed ma simile a quella che si ha in una sequenza di repliche. Fra le due sono avvenuti gli eventi più forti. Il valore medio di b, dalla relazione frequenza-magnitudo, is stato alto: $1.77 \pm 0.15$. Inoltre, durante lo sciame, detio parametro ha subito variazioni (una diminuzione da 1.8 a 1.1 seguita da lun bruseo anmento fino a 2.5 dopo i terremoti più forti o la principale eruzione vuleanica).

I) a AR furono ottenuti valori del momento sismico per 118 terremoti che furono ben recristrati dai sismografi a lungo periodo. Altre caratteristiche alla sorgente furono determinate dalla difierenza fra il logaritmo del momento sismico e la mannitulo locale. I parametri alla sorgente furomo trovati insolitanente grandi. Durante lo sciane fu evilenziata una variazione nel tempo delle proprieta della sorgente. La variazione dello spostamento mostra inoltre ma correlazione inversa alla variazione del coefficiente b.

Lo sciame ha fornito fasi molto nette di $T$, ben registrate dall idrofono vicino all isola di Wake e dalle stazioni sismiche installate lungo l'Aleo delle Tonga rivolto verso l'Oceano, non recristrate invece da quelle site all interno dell Areo delle isole stesse.

Vn confronto fra le ampiezze delle onde $T$ registrate dall idrofono presso l'isola Wake e le mannitudo delle onde spaziali, dimostra che 9 eventi hanno immesso quantiti di encrgia eccezionalmente ampie nello strato SOFAR. Questi eventi vengono interprotat come eruzioni vulemiche sottomarine.

\section{INTRODLCTION}

An earthquake swarm, beginning on $11 \mathrm{July} 1973\left(^{*}\right)$, took place neal Curacoa Reef, at the extreme northern end of the Tongal are, shortly before an observel volcanic eruption.

(*) Unless otherwise stated, dates and times are Universal Time: this is 13 hours behind local Tongan time, and 11 hours ahead of samoan time. 
Locations of earthquakes of the Curaçoa Reef swarm, seismograph stations in the area, active voleanoes (24), island ares, and ocean trenches are shown in Fig. 1.

This is an area in which the tectonics are relatively well understood $\left({ }^{6}, 18,22\right)$. Focal mechanisms of shallow earthquakes from the main part of the Tonga arc, confined to the region between the trench axis and the volamoes and defining the common boundary of the Pacific and Australian plates, indicate that the Pacific Ocean floor underthrusts the arc to the west along shallow dipping fault planes.

The fault plane solutions for shallow earthquakes from the northern end of the arc are different. They reflect dip-slip motion on nearly vertical, easterly striking faults with the south sirle moving downward (16, 18). These earthquakes are associated with the formation of a hinge fault within the Pacific plate rather than with movement of one plate past another, and higher stress at the northern end might therefore be expected than elsewhere in the zone (16). Highly concentrated stress in very heterogeneous material is known to be neerled for the generation of swarm-type sequences of earthquakes (21).

Although the sequence lasted only 2.3 days, it produced 564 shocks of magniturle $M_{L} \geqslant 3.4$. The number of recorded events is therefore large enough for the pattern of the swarm to be consirlered in terms of the rate of occurrence of events, the frequency-magniturle relationship, and the variation of both parameters with time. All these are important rlues to an understanding of swarm-type sequences (12). Association of the earthquakes with an observed volcanic eruption adrs further in terest to this sequence in terms of the problem of the interdependence of volcanic and seismic events.

The spectral theory of earthquake sources $(2,5,6,19,23)$ provirles a powerful technique for evaluation of source properties, which are themselves of great importance for a better understanding of tectonic processes. Different source materials or different tectonic environments can influence source parameters, and these can be determined from the varying amplitule spectra of the raliated waves. The technique becomes very simple when the seismic moment and local magniturle $M_{L}$ alone are suficient to estimate other source characteristics (13), especially as the seismic moment can be estimated from the long-perion parameter $A R(F)$. A number of the larger earthquakes throughout the Curacoa Reef sequence were recorderl on both shorl- and long-period seismoglaphs at Afiamalu, and this allows the time variation of source properties during the swarm to be considered. 
1) NTA

Seismograph stations in the region, from which records were available, are those shown in Fig. 1. Vunikawai (VUN) in Fiji and Teeklu (TEK) in Tonga are operated by Cornell University, New York, U.S.A. All other stations, Afiamalu (AFI), Apia (API), Nine (NUE), Rarotonga (RAR), and Raoul Island (RAO), are controlled by the Seismological Observatory, Wellington, New Zealand. Two of them, IFI and RAR, are part of the World-Wide Standard Seismograph Tetwork.

IFI station, situated about $250 \mathrm{~km}$ from the centre of the swarm activity, recorded over 600 earthquakes of the sequence. The seismograms from $\triangle P I$, located about $10 \mathrm{~km}$ from the $\triangle F I$ station, were used to cover periods during which the $A F I$ records were being changed. NUE station, situated about $600 \mathrm{~km}$ from the swam, recorted over 400 shocks, and $\mathrm{RAR}$, at a clistance of about $1700 \mathrm{~km}$, recorded in most cases $T$ phases only in a total of about 300 events. RAO station did not record any, probably due to the rather high noise level at the time. VUN and TEK recorded only a few of the largest events.

Generally only thee stations were available for location of epicentres, which are, accordingly, very approximate. Both $P$ and $S$ waves were used when available. A total of 105 events were locater. The epicentres of these are shown, roughly, in Fig. 1. For relative locations, intervals between $T$ phase arivals were employed. The three largest events in the swarm (all those of $M_{L}>4.5$ ) are shown in Fig. 2, together with all inferred volcanic eruptions, all of which took place after the largest eathqukes. Only the largest event $\left(M_{L}=5.1\right)$ was located by NOA.

The frequency response of the short-period seismographs at AFI, NUE, and RAR is shown in Fig. 3. The long-period Press-Ewing seismographs at AFI recorded 118 of the events well, and these records have been used for estimation of the seismic moment of the earthquakes.

Records from four hydrophones located near Wake Island have been supplied by the University of Hawaii. These instruments are part of the Pacilic Missile Range Facility, operated by the U.S. Department of the Navy. One hydrophone, situated about $180 \mathrm{~km}$ southeast of Wake Island, recorded $T$ waves from more than 3500 events during the periorl of the swarm. The others recorded $T$ waves from the largest events only. 


\section{SPACE DISTRIBUTION}

From the epicentres determined, it is possible to estimate approximately the size of the swarm zone. The zone has slightly elliptical shape with semi-axes of $50-60 \mathrm{~km}$. This rough estimation agrees very well with the range of changes of $S-P$ intervals during the swarm. Values of $S-P$ intervals at $A F I$ station vary from 24 s to 37 s. Comparison of arrival times of $T$ phases at the hydrophone southeast of Wake Island with origin times rletermined from body waves on the seismograms agrees closely with this interpretation. An overall maximum alimension of the swarm area of about $60 \mathrm{~km}$ is indicated from the great majority of events, extreme cases falling in an area about twice as great.

The estimated size of the swarm area, therefore, is anomalously large for the relatively small earthquakes which occurred during the sequence. Swarms are generally much morespatially compact, although few studies have been made of this aspect of their occurrence. Data from aftershock sequences also tend to give much smaller values for the size of aftershock zones. A main shock of magniturle $M_{L}$ about $73 / 4$ would, in general, be associaterl with a circular fault area of radius half as large as that obtained for the present case $\left({ }^{11,20}\right)$, in which the largest event was only of magnitude $M_{L}=5.1$. The unusually large size of the zone suggests that the swarm probably oceured in a weak and badly fractured region, stress being spread over a correspondingly wider area than usual.

\section{Generation of $T$ phases}

The special attention paid to $T$ phases in this study arises from the need to use them for the retermination of magnitudes for the smaller earthquakes in the swarm. In fact, in most cases the only phase distinctly recorcled was the $T$ wave.

$T$ waves propagate as sound waves through water. They generally only propagate in water deeper than about $2 \mathrm{~km}$. Their propagation is affected by the layered structure of oceans, and in shallow water probably by the ocean-floor topography. Furthermore, the bottom topography plays a very important part in the generation of $T$ phases ('). The hydro-acoustic waves do not emanate from a point but are expansions of the seismic wavefront. Their region of initiation is generally distinctly different from that of the epicentre of the earthquake $\left.{ }^{8}\right)$. 
$T$ waves observer at stations located on the oceanic side of the Tonga Trench (AFI, NUE, RAR; see Fig. 1) are by far the strongest phases recorrled in the events of this sequence, with amplitudes several times larger than those of $P$ and $S$ waves. On the other side of the trench, that on which the earthquake origins themselves are located, $T$ phases were not observed at any of those stations for which records are available (TEK at a distance of about $700 \mathrm{~km}$ from the swarm, VUN at about $800 \mathrm{~km}$, and $\mathrm{RAO}$ at about $1700 \mathrm{~km}$ ). It is hardly surprising that TEK and RAO have failed to record $T$ waves, since these would have had to travel along the ocean ridge forming the TongaKermarlec arc. Similarly, the shallow water around Fiji would inhibit the transmission of $T$ phases to VUN. The most convincing explana-

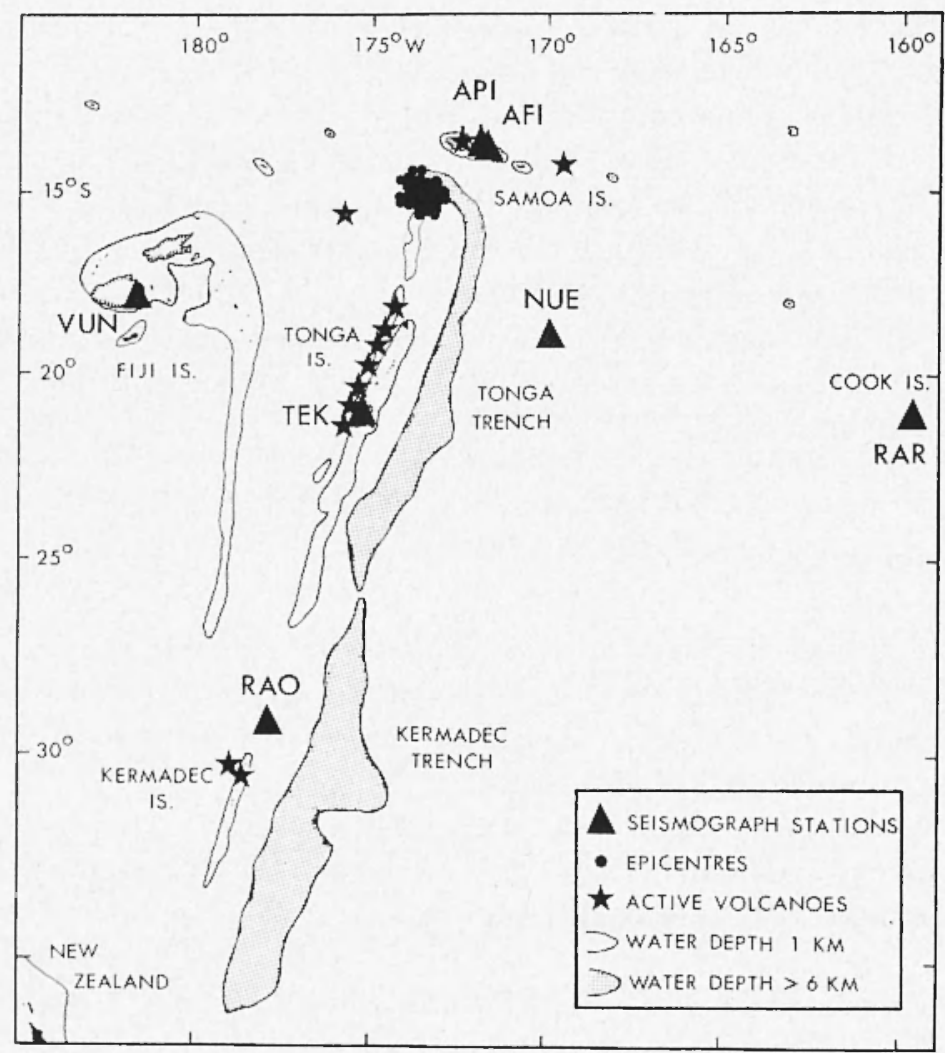

Fig. I - Epicentres of located carthquakes in the swarm, seismograph stations, and active volcanoes in the region. 


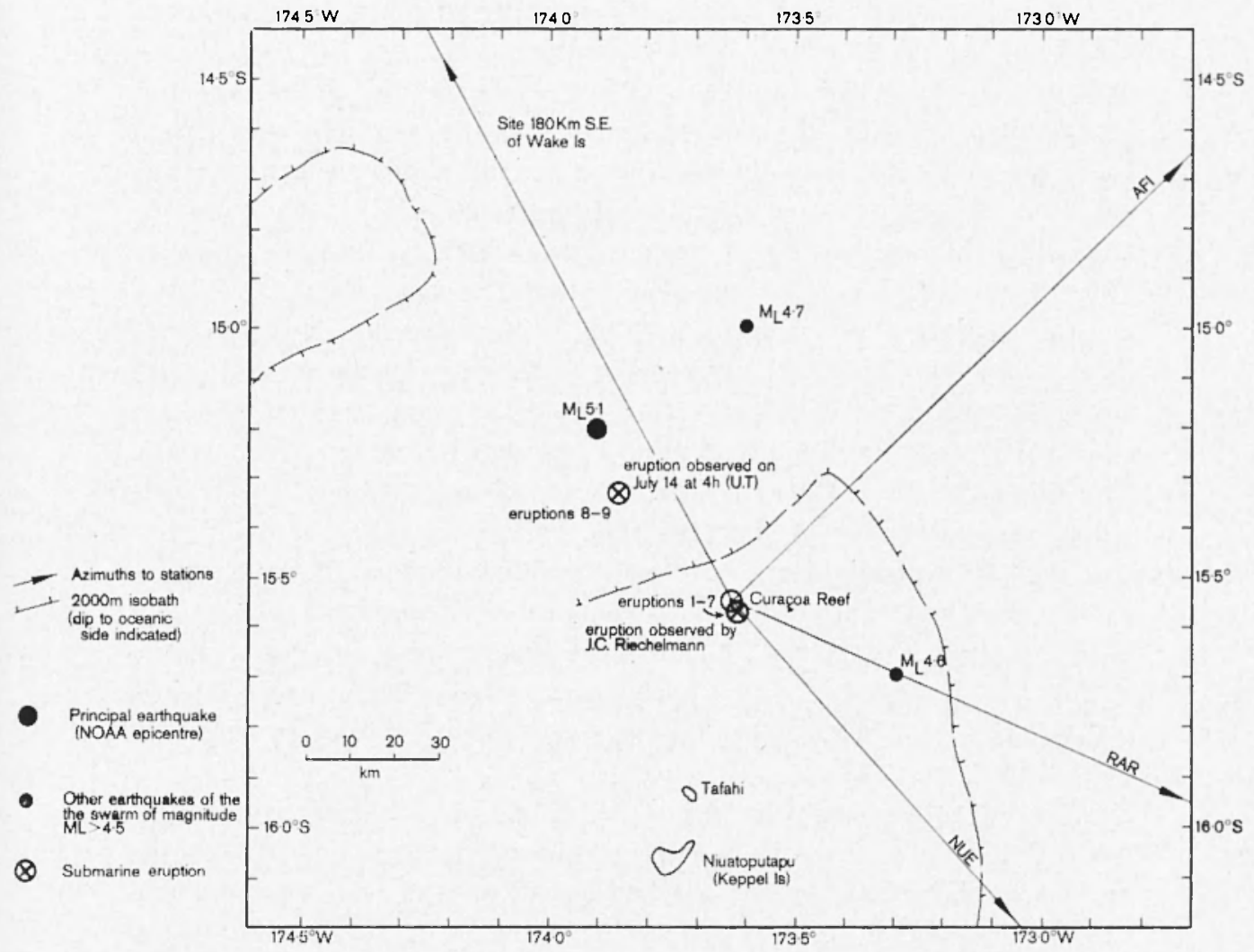

Fig. 2 - Curaçoa Reof locality map, showing sites of inferred volcanic cruptions (numbered in accordance with Table II), and the epicentres of the largest earthquakes in the swarm $\left(I_{L}>4.5\right)$.

tion appears to be that the area of $T$-phase generation lay along the Tonga Trench, so that it was only those seismic waves which crossed the trench that gave rise to hydro-acoustic waves. The ridge would have obstructed and weakened $T$ waves travelling along it from the trench area, enough to prevent them from being recorded by those stations located in the ridge area itself.

This conclusion is supported by the travel time of observed $T$ phases. Their time of arrival at AFI station is much the same as that expected for the SOF $A R$ velocity $v_{T}=1.48 \mathrm{~km} / \mathrm{s}\left({ }^{17}\right)$. The difference between the distance from the earthquake origins and their hydroacoustic source areas is in this case probably negligible. 
It is not so for NCE and R.AR stations, however, since in these directions the ocean trench lies at some distance from the earthquake origins. Travel times observed at these stations and those expected for the given velocity are shown in Fig. 4 . In both cases, observed travel times are much less than those expected for the same epicentral clistances, thus suggesting much shorter distances travelled by the $T$ waves, or a much higher velocity of propagation, which would in fact require to be more than the very improbable figure of $1.6 \mathrm{~km} / \mathrm{s}$.

The satter of observations at NUE is very large and no consistent dependency on epicentral distance is observed. It seems that even small changes in earthquake position would have consinlerable influence on the efficiency of $T$-wave generating areas within the trench with respect to the NUE station, especially as the curvature of the trench would also affect travel times to this station.

The RAR observations are much more consistent. Their slowness is that of $P$ waves, which suggests constant $T$-wave paths. The point of intersection of expected and observed lines gives a generation point within half a legree of the closest earthquakes. This means that $T$ waves from more distant arthquakes travel as $P$ waves to the erlge of the trench.

Travel times shown in Fig. 4 are those of the group containing maximum amplitudes. They were preceded within about 25-30 s by an emergent phase observed only on the recorts of the larger events.

Amplitules of $T$ phases are sensitive not only to the usual factors affecting other seismic waves, but also to ocean-lloor topography. The topography of the Tonga Trench, therefore, is probably responsible for a considerable scatter in the ampliturle data. Nevertheless, it is clear that such data can be of value in the determination of magniturle.

\section{MACXITUDE OF FARTHQUAKES}

Ampliturles of $P$ and s waves, recorded at $A F T$ and XUE, represent the basic data for the determination of magnitule. Two possible methors can be used to calculate values of the local maniturle $M_{L}$. On the one hand, the observer maximum amplitudes of $S$ waves, realculated into the amplitules that would have been recorded by a standard Wood-Anderson seismograph, can be used to give $M_{L}$ according to Richter's original definition $\left({ }^{25}\right)$. Alternatively, amplitudes of $P$ waves, or more precisely their amplitudes divided by periods, corrected 
for the distance effect by using the amplitude-distance curves obtained from New Zealand earthquakes (9), conld also be alequate for determining $Y_{L}$, especially when observations are limited to the narow range of distances from a single station. Both methorls have their disadvantages, so that the values of $M_{L}$ calculated independently by each methor need to be carefully compared and evaluated.

$M I_{L}$ values calculated at $I F I$ from $S$ waves are compared with those calculated from $P$ waves in Fig. 5. Values estimated from $P$ waves are consistently higher by about 0.7 than those obtained from $S$ waves. On the other hand, $M_{L}$ values from $P$ waves recorded at AFI are comparable to those from $S$ waves recorded at NUT (Fig. 6), although the scatter is considerable, due mainly to errors in reading the very small amplitules of borly waves observed at NUE. The result is not surprising considering the shape of the frequency response of the seismographs at AFI and XUE, and of the standard Wood-Anderson instrument (Fig. 3).

Recalculation of the observer $s$ ampliturles, into those which would have been recorded by the standard instrument, involves an assump. tion that maximum amplitude recorted by a given seismograph would also have been the maximum when recorded by the standard WookAnderson. This is true only when the shape of frequency response of both instruments involved is irlentical or at least very similar.

The frequency response of the seismograph at NUE is indeed similar to that of the standard, but this is not the case at IFI. Therefore, the values of $I_{L}$ obtained from $s$ amplitudes recorden at NEL can be expected to be close to the true values, and this implies that the values obtainer from $P$ waves recorded at AFI are also approximately correct. Possible regional eflects on the amplitude-distance relationship, that is, the difference between the attenuation of $S$ waves in Southern California, on which the original definition of $M_{L}$, was based (25), and the attenuation in the Curagoa Reef area, seems to be negligible, since this effect would have influenced both stations, and not only AFI.

Amplitules of $T$ waves, the strongest phase recorded, are characterised by a large scatter, due probably to differences in ocean-floor topography at the places where the waves were generated. Nevertheless, the number of $I_{L}$ values found from $P$ ampliturles is sufficient for an attempt to be made to correlate $T$ ampliturles with magnitude values. This correlation can be used in turn for estimation of magniturle for smaller shocks, for which only $T$ waves were recorded.

Values of $A / T$ of the $T$ plase recorrled at $A F I$ versus $M_{L}$ are 


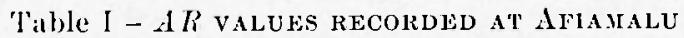

\begin{tabular}{|c|c|c|c|c|c|c|c|}
\hline Date & $\begin{array}{l}\text { Time } \\
\text { (U.'T') } \\
\text { h. m. }\end{array}$ & $M_{L}$ & $\begin{array}{l}A R_{250} \\
\left(\mathrm{~cm}^{2}\right)\end{array}$ & Date & $\begin{array}{l}\text { Time } \\
\text { (I'T.) } \\
\text { h. 'm. }\end{array}$ & $M_{L}$ & $\begin{array}{l}A R_{250} \\
\left.(\mathrm{~cm})^{2}\right)\end{array}$ \\
\hline \multirow[t]{41}{*}{ July 11} & 1010 & 3.7 & 3.7 & \multirow{41}{*}{ July 12} & 2248 & 5.1 & 116 \\
\hline & 1257 & 3.7 & 4.9 & & 2257 & 4.4 & 13.7 \\
\hline & 1311 & 3.7 & 2.1 & & 2304 & 3.9 & 4.7 \\
\hline & $14 \quad 16$ & 3.8 & 8.0 & & $23 \quad 11$ & 3.9 & 3.4 \\
\hline & $14 \quad 35$ & 3.6 & 1.5 & & 2316 & 3.6 & 1.5 \\
\hline & 1610 & 4.0 & 5.9 & & 2320 & 3.9 & 3.5 \\
\hline & 1621 & 3.7 & 1.5 & & $23 \quad 25$ & 4.1 & 2.4 \\
\hline & 1629 & 4.6 & 18.8 & & 2329 & 4.5 & 5.9 \\
\hline & 1646 & 3.6 & 2.2 & & $23 \quad 37$ & 3.9 & 3.4 \\
\hline & 1650 & 3.9 & 3.7 & & $23+5$ & 4.2 & 4.8 \\
\hline & 1707 & 3.9 & 5.8 & & $23 \quad 58$ & 4.1 & 2.5 \\
\hline & 1716 & 3.6 & 1.2 & & 0008 & 4.4 & 6.5 \\
\hline & 1730 & 4.2 & 16.2 & & 0015 & 4.1 & 4.3 \\
\hline & 1746 & 3.9 & 7.5 & & 0021 & 4.0 & 3.2 \\
\hline & 1822 & 3.9 & 4.9 & & 0044 & 4.1 & $(3.9)$ \\
\hline & 1830 & $(3.8)$ & 2.1 & & 0047 & $(4.2)$ & 5.6 \\
\hline & 1834 & 4.0 & 4.5 & & $01 \quad 02$ & 4.2 & 7.1 \\
\hline & 1839 & 4.0 & 2.7 & & $02 \quad 27$ & 3.7 & 1.7 \\
\hline & 1849 & 4.2 & $(10)$ & & 0236 & $(4.1)$ & $(4.6)$ \\
\hline & 1854 & 4.4 & 16.0 & & $02 \quad 39$ & 4.3 & 6.8 \\
\hline & 1900 & $(3.6)$ & 2.5 & & $02 \quad 55$ & 3.7 & 1.4 \\
\hline & 1905 & 3.9 & 3.1 & & $03 \quad 37$ & 4.2 & 11.8 \\
\hline & 1910 & 3.6 & 2.0 & & 0338 & $(4.0)$ & 2.6 \\
\hline & 1922 & 3.9 & 4.7 & & $03 \quad 42$ & 3.9 & 4.5 \\
\hline & 1942 & $(3.9)$ & $3 . \tilde{5}$ & & $04 \quad 12$ & 3.7 & 1.3 \\
\hline & 1950 & 4.3 & 10.6 & & $04 \quad 17$ & 3.6 & 1.0 \\
\hline & 1959 & 3.9 & 2.6 & & $04 \quad 32$ & 3.8 & 1.2 \\
\hline & $20 \quad 16$ & $(4.2)$ & 7.5 & & 0450 & 3.6 & 1.6 \\
\hline & 2038 & 4.0 & 1.9 & & 0506 & 3.8 & 2.9 \\
\hline & 2041 & 4.1 & 3.3 & & $05 \quad 16$ & 3.9 & 3.5 \\
\hline & $21 \quad 16$ & 3.9 & 3.3 & & $05 \quad 22$ & 3.6 & 1.7 \\
\hline & 2120 & 4.1 & 3.2 & & $05+1$ & 3.7 & 1.5 \\
\hline & 2128 & 4. 2 & 5.8 & & 0556 & 3.7 & 2.1 \\
\hline & 2141 & 3.9 & 2.5 & & 0600 & $(3.6)$ & 1.4 \\
\hline & 2149 & 3.6 & 1.5 & & $06 \quad 21$ & 3.7 & 1.2 \\
\hline & 2156 & 4.1 & 3.1 & & 0623 & 3.7 & 2.0 \\
\hline & $22 \quad 05$ & 3.9 & 1.7 & & 0629 & 3.6 & 1.8 \\
\hline & $22 \quad 14$ & 4.1 & 3.8 & & 0630 & $(3.5)$ & 1.1 \\
\hline & $22 \quad 20$ & 4.2 & 4.8 & & $06+1$ & 3.7 & 1.2 \\
\hline & $22 \quad 27$ & 3.9 & 2.4 & & 0700 & 3.8 & 1.7 \\
\hline & $22+5$ & 4.1 & $(4.2)$ & & 0714 & $(3.5)$ & 1.1 \\
\hline
\end{tabular}




\begin{tabular}{|c|c|c|c|c|c|c|c|}
\hline Date & $\begin{array}{l}\text { Time } \\
\text { (U.'T.) } \\
\text { h. m. }\end{array}$ & $M_{L}$ & $\begin{array}{l}A R_{250} \\
\left(\mathrm{c} \mathrm{m}^{2}\right)\end{array}$ & Date & $\begin{array}{l}\text { Time } \\
\text { (U.T.) } \\
\text { h. m. }\end{array}$ & $M_{L}$ & $\begin{array}{l}A R_{25 n} \\
\left(\left(\mathrm{~cm}^{2}\right)\right.\end{array}$ \\
\hline July 12 & $\begin{array}{ll}07 & 19 \\
07 & 37 \\
07 & 50 \\
08 & 27 \\
08 & 30 \\
08 & 52 \\
09 & 04 \\
09 & 27 \\
09 & 30 \\
09 & 43 \\
09 & 52 \\
10 & 26 \\
10 & 39 \\
10 & 41 \\
11 & 45 \\
12 & 18 \\
12 & 56 \\
14 & 39\end{array}$ & $\begin{array}{c}4.7 \\
3.8 \\
(4.0) \\
3.7 \\
(3.5) \\
3.5 \\
3.7 \\
3.5 \\
(3.5) \\
3.4 \\
(3.4) \\
(3.5) \\
(3.5) \\
(3.7) \\
3.7 \\
3.5 \\
3.7 \\
3.7\end{array}$ & $\begin{array}{r}65.0 \\
4.5 \\
3.1 \\
1.4 \\
1.3 \\
1.3 \\
1.6 \\
1.1 \\
1.3 \\
1.0 \\
1.0 \\
1.1 \\
1.2 \\
1.6 \\
2.0 \\
1.0 \\
1.5 \\
1.4\end{array}$ & & $\begin{array}{ll}14 & 44 \\
15 & 13 \\
15 & 35 \\
15 & 44 \\
15 & 49 \\
15 & 55 \\
15 & 57 \\
16 & 05 \\
17 & 25 \\
17 & 36 \\
18 & 10 \\
19 & 15 \\
20 & 00 \\
21 & 53 \\
21 & 58 \\
22 & 23 \\
23 & 03 \\
23 & 23\end{array}$ & $\begin{array}{c}3.7 \\
3.4 \\
3.7 \\
4.3 \\
(3.7) \\
(3.5) \\
(3.4) \\
(3.5) \\
3.7 \\
(3.5) \\
3.7 \\
(3.7) \\
3.7 \\
4.0 \\
(3.5) \\
3.5 \\
3.7 \\
(3.5)\end{array}$ & $\begin{array}{r}1.5 \\
1.1 \\
1.9 \\
18.1 \\
3.2 \\
1.5 \\
1.2 \\
1.7 \\
1.6 \\
1.6 \\
2.0 \\
1.8 \\
1.6 \\
3.7 \\
1.5 \\
1.6 \\
1.8 \\
1.4\end{array}$ \\
\hline
\end{tabular}

Table II - Evests In tie Curaçoa ReeF swarm interpretel) as SUBMARINE VOLCAYIC ERUPTIONS.

\begin{tabular}{|c|c|c|c|c|}
\hline No. & Date & $\begin{array}{l}\text { Time } \\
\text { (U.T.) } \\
\mathrm{h}_{\mathrm{l}} \mathrm{m}\end{array}$ & Group & Remarks \\
\hline $\begin{array}{l}1 \\
2 \\
3 \\
4^{*} \\
5 \\
6 \\
7 \\
8 \\
9^{*}\end{array}$ & July 12 & $\begin{array}{ll}07 & 55.4 \\
11 & 21 .(9) ! \\
12 & 53.6 \\
13 & 14.1 \\
13 & 46.0 \\
14 & 15.7 \\
19 & 46.9 \\
03 & 34.5 \\
03 & 38.6\end{array}$ & $\begin{array}{l}\text { III } \\
\text { IV }\end{array}$ & $\begin{array}{l}\text { By far the largest eruption. } \\
\text { The eighth in order of size. } \\
\text { The sixth in order of size. } \\
\text { The second largest. } \\
\text { The third langest. } \\
\text { The fifth in order of size. } \\
\text { The smallest eruption. } \\
\text { The fourth in order of size. } \\
\text { About the same size as No. } 3 \text {. }\end{array}$ \\
\hline
\end{tabular}

(*) Events which grenerated detectable body waves. In other cases only $T$ waves were recorded. The size of the eruptions is judged from the relative amplitules of these $T$ waves, 


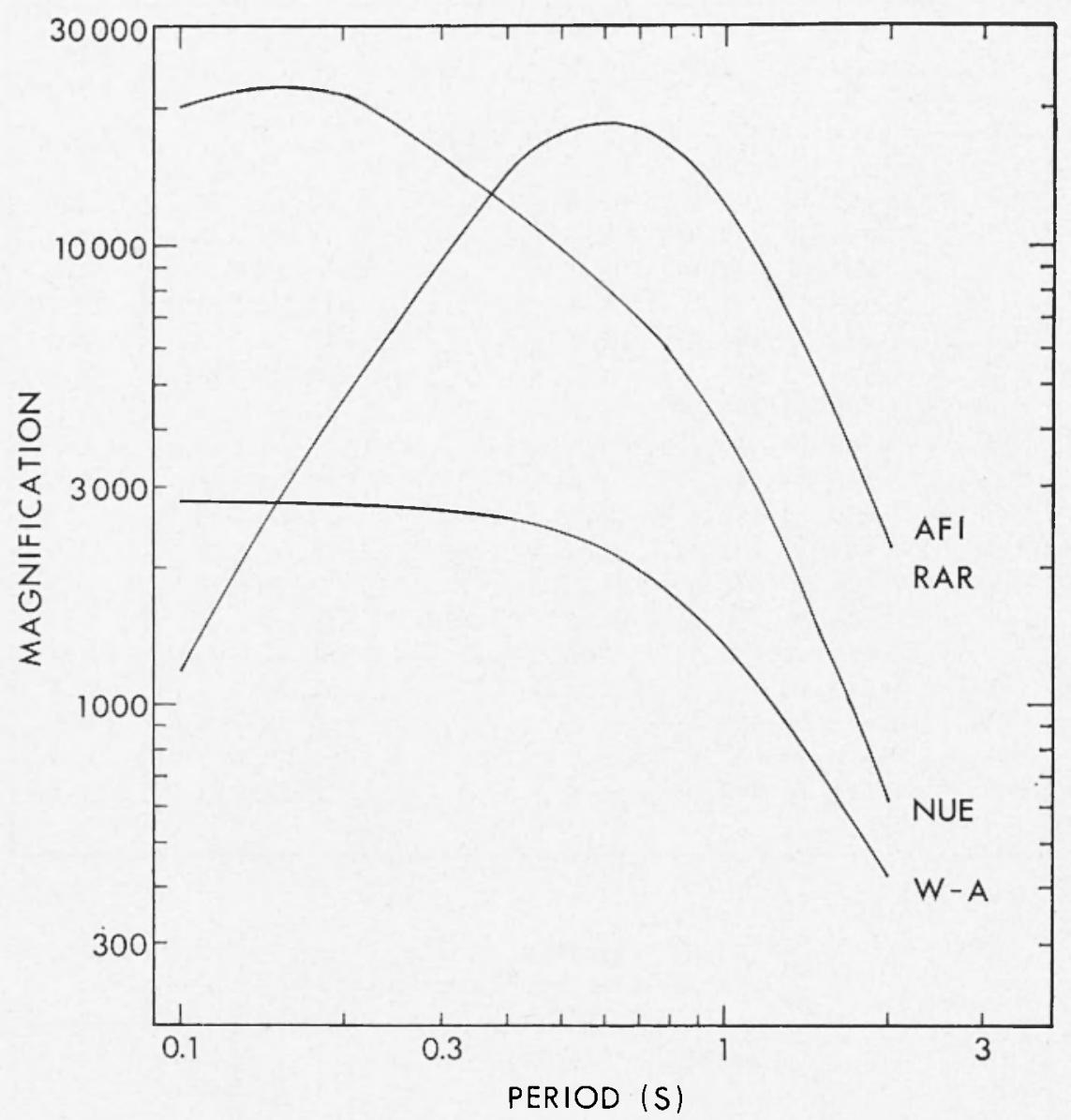

Fig. 3 - Frequency response of the seismographs at Afiamalu (AFI), Nine (N (E) and Rarotonga (RAR), and of the stamdard Wood-Anderson (WV-A) inst rument.

shown in Fig. 7 . T amplitudes are much more sensitive to magnitule changes than are those of body waves. They vary, in fact, with

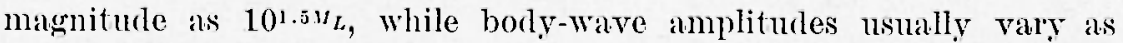
$10 w_{L}$. Thus a change in $T$ amplitude about three times that of the $P$ or $s$ amplitudes is required for the same amount of change in magnitude value. This difference in behaviour towards magnitude is of considerable importance when considering the frequency-magnitude relationship. 


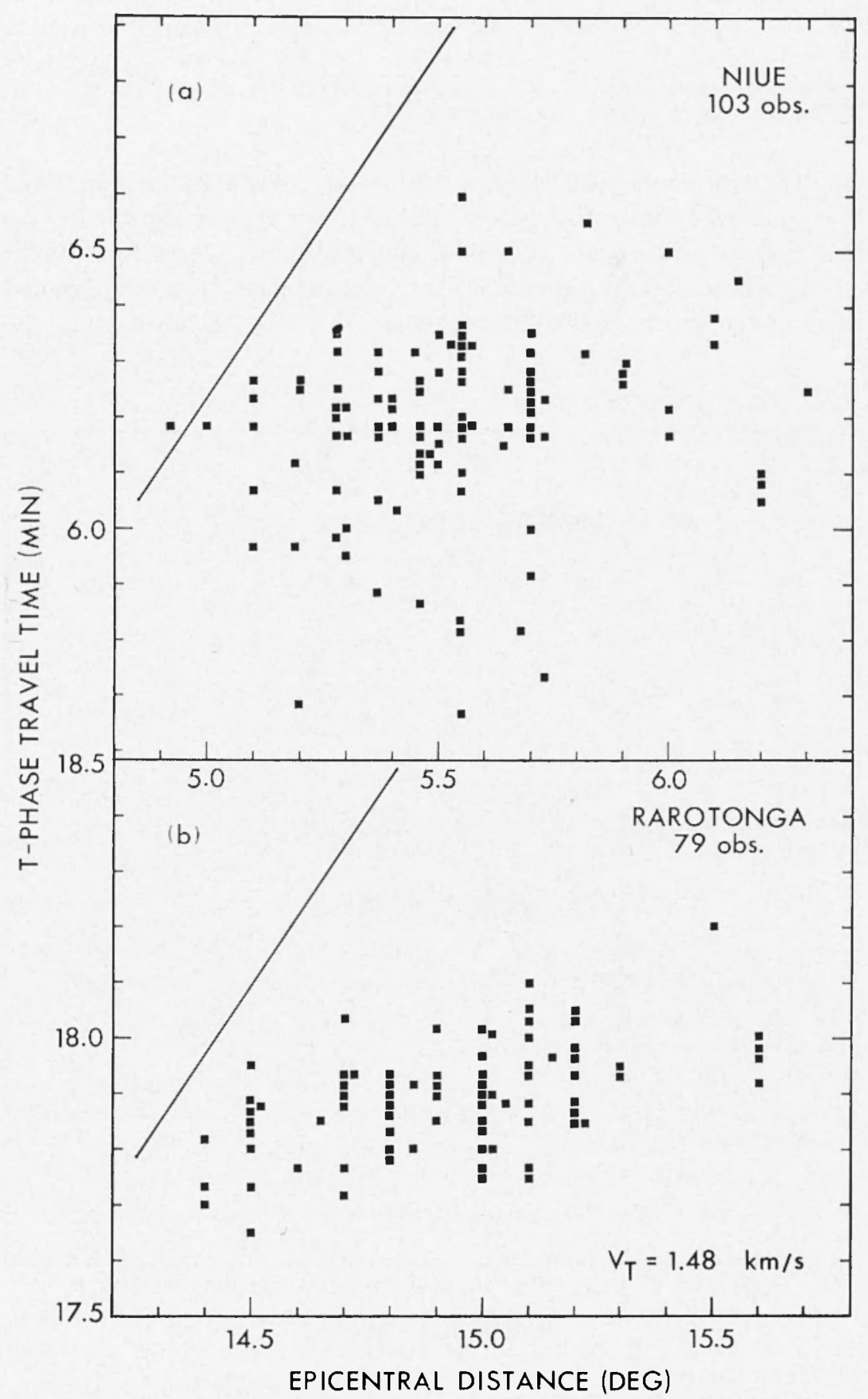

lig. 4 - Travel time of $T$-phases observed at Nine (a) and Rarotonga (b). The expected travel times for the velocity $V_{T}=1.48+\mathrm{km} / \mathrm{s}$, at these epicentral distanees, are shown by solid lines. 


\section{RATE OF EARTHQUAKE OCCURRENCE}

The first shock took place at $03^{n} 15^{m}$ on $11 \mathrm{July}$ and was followed by two shocks within two hour's. The activity then stopped for over four hours, starting again at $09^{\mathrm{h}} 03^{\mathrm{m}}$, and continuing thereafter without any significant breaks throughout the next 2.3 days. The conventional onset of the swarm is therefore taken as $09^{n} 03^{m}$ on $11 \mathrm{July.}$

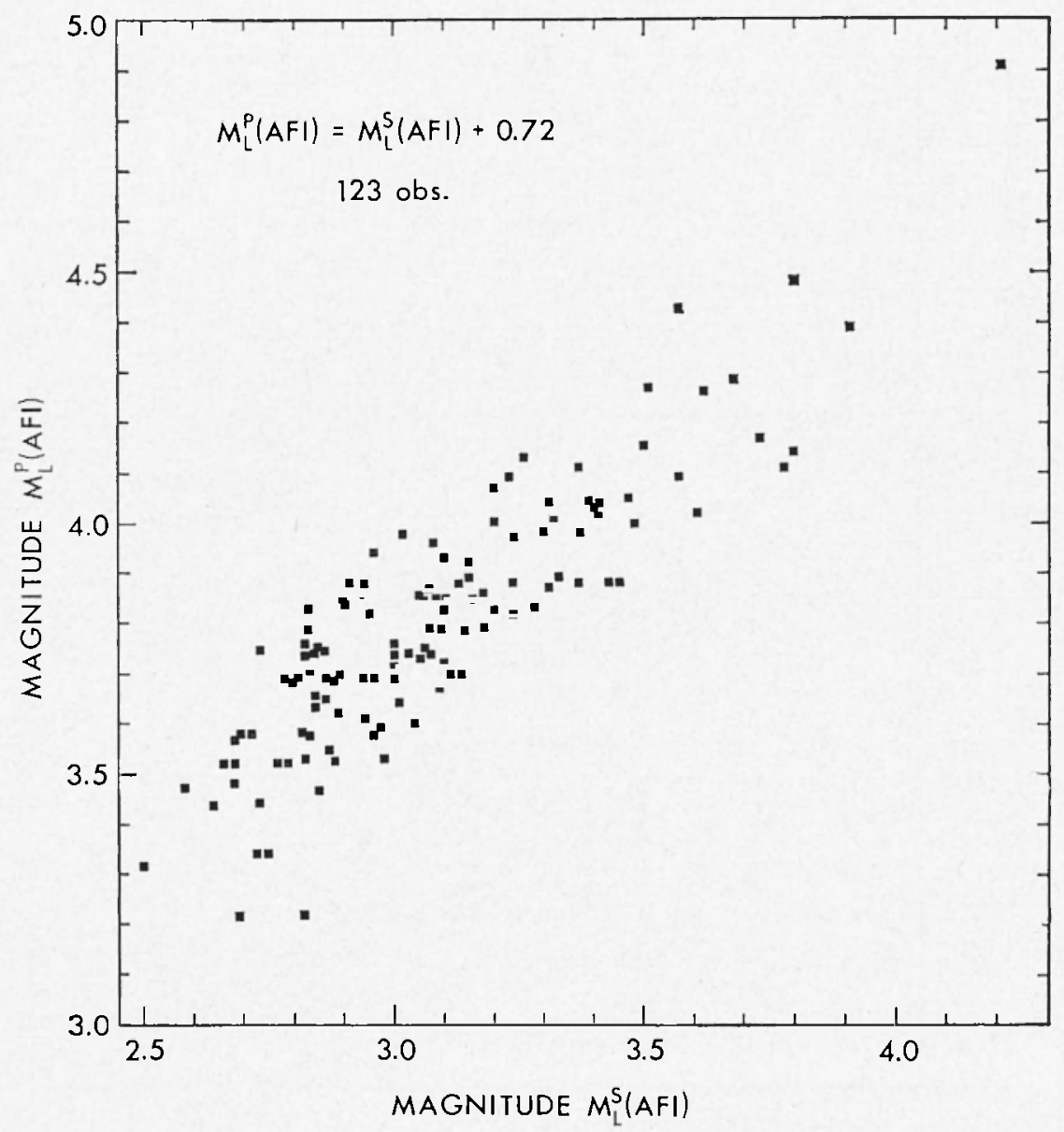

Fig. 5-Comparison of magnitude $I_{L}$ - values calculated from $S$-waves with those from $P$-waves recorded at Afimalu. 


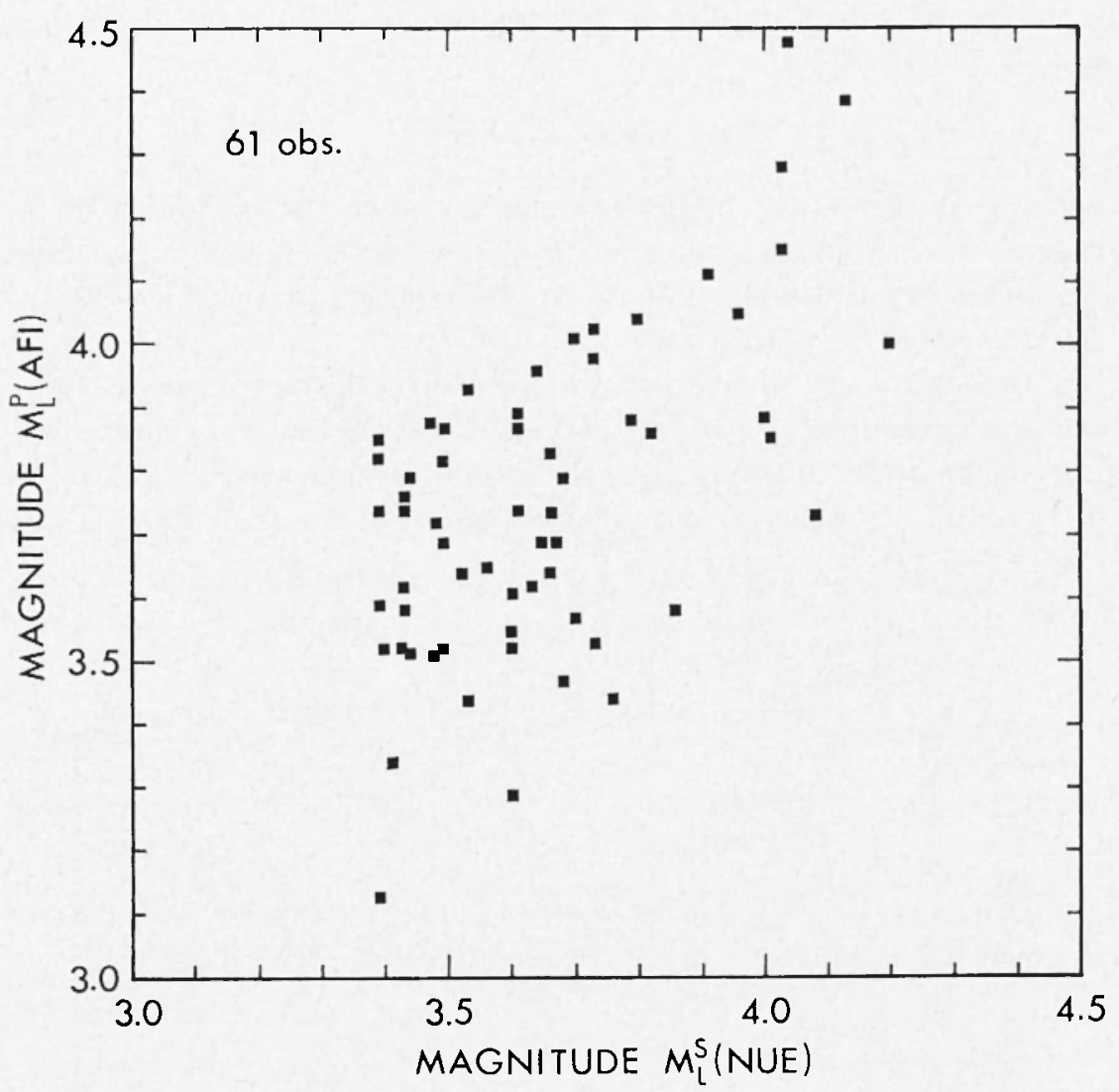

Fig. 6 - Comparison of magnitude $Y_{L}$ values caleulated from $S$-waves observer at Niue with those from $P$-waves recorded at Afiamalu.

The rate of earthquake occurrence $n$ is given by the number of shocks per unit time above some given magnitude threshold. The number of shocks in successive three-hour intervals is shown in Fig. 8 , which illustrates the variation of the rate of occurrence during the swarm. The magnitude threshold, above which it is considered that all earthquakes were detected, is 3.4 .

The rate of occurrence can also be presented in a different form, more easily comparable with the rate during other sequences of earthquakes. If $\Delta N$ is a fixed number of shocks, and $\delta t$ the variable time interval during which they occur,

$$
n=\Delta N / \delta t \text {. }
$$


The rate of occurrence of aftershocks, as a function of time, is usually expressed by

$$
n=n_{1} \cdot t^{p}
$$

where $n_{1}$ is the rate of occurrence one day after the beginning of the swarm, $p$ is a constant, and $t$ is the time from the beginning in days. The value of $y$ is usually close to -1 , which means that the activity decays hyperbolically with time $\left.{ }^{30}\right)$.

Generally, earthquake swarms have several stages, during which the rate of occurrence increases and decreases alternately. These changes can be approximated, as in the case of aftershocks, by a formula of type [2]. In general, the value of $p$ during the final stage is also close to $-1\left({ }^{12}\right)$.

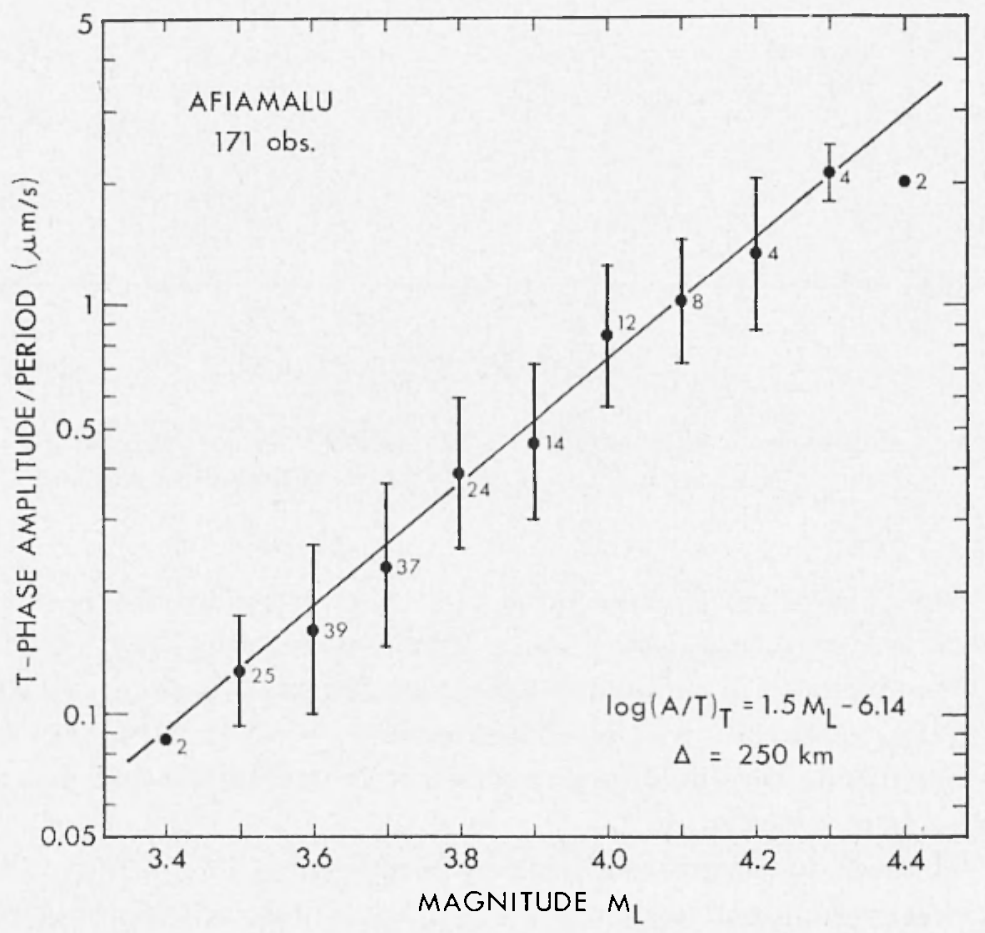

Fig. 7 - Values of amplitule/period of $T$-phase versus magnitule $H_{L}$ for an cpicentral distance of about $250 \mathrm{~km}$. Standarl deviations for each magnitule value are shown by vertical hars: the number of observations is griven. 


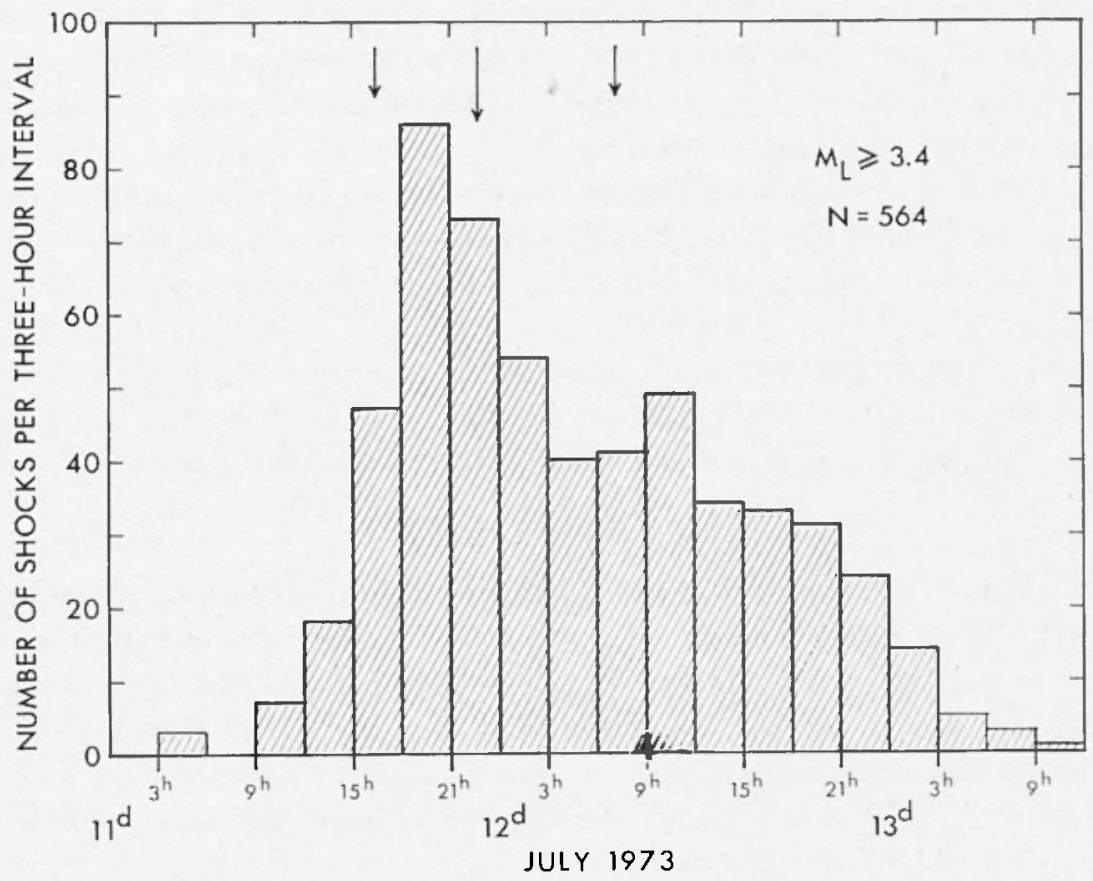

Pigr. 8 - Number of shocks in suecessive three-hour intervals during the swarm. The arrows show the time of occurrence of earthquakes with $Y_{L}>4.5$. The largest is shown with a Ionger arrow.

This pattern is followed by the Curaçoa Reef swarm. The rate of occurrence, calculated from formula [1], versus time, is shown in rig. 9. Values are calculater for sets of 50 shocks, spacer at intervals of 25 shocks, and assigned to the mean of each time interval involver. The swarm displays two stages, the rate first increasing and then decreasing. This is similar to a typical foreshock-aftershock pattern, although in this case the "foreshock" stage was much more vigorous than in the case of a normal foreshock sequence. The pattern is of type $B$ according to the recently proposed classification for swarm activity (12). This seems to be the most common pattern for swarms of relatively short duration (those lasting for only a few days).

The largest earthquakes occurred in the mirllle of the swarm. An event of magnitude $M_{L}=4.6$, occurring during the first stage of the swarm, had no effect on the rate of occurrence, which continued to increase smoothly. The largest shock of $M_{L}=5.1$ appeared about two 
hours after the activity reached its peak, and this had no clear effect on the rate of occurrence either, while an earthquake of $M_{L}=4.7$, occurring later, during the second stage, was followed by a small sequence of aftershocks (see Fig. 9).

All events considered to have been volcanic eruptions (see cliscussion below) took place during the second stage of the activity.

\section{FreqUeNCY-MLAGNITUDE RELATIONSHIP}

The frequency-magnitucle relationship is commonly written

$$
\log N_{M}=a-b M
$$

where $N_{M}$ is the number of earthquakes within a given magnitude interval $M \pm \Delta M / 2$, and $a$ and $b$ are constants (14). The constant $a$ is not an independent quantity. The best way in which to determine the constant $b$ is to use the maximum likelihood method of Utsu (31). Its quality can be estimater from the confidence limits calculated by Aki's method (1). When the magnitude interval is large, special corrections to the $b$ values must be applied $\left({ }^{32}\right)$.

The frequency-magnitude relationship for the whole Curaçoa Reef swarm is shown in Fig. 10. The adopted magnitude interval is $\Delta M=0.3$, since most of the $M_{L}$ values are based on ampliturles of $T$ phases, which are more sensitive to magnitude changes than those of body-waves. Even so, the interval is that typically used during studies of several earthquake sequences in New Zealand $\left({ }^{10}\right)$. The value of $b$ at $95 \%$ confirlence limits for the whole sequence is $1.77 \pm 0.15$. This value is much higher than those typically observed from nonvoloanic sequences, implying, perhaps, that the stress field was primarily of thermal origin, directly related to underground volcanic processes ( $\left.{ }^{33}\right)$. This implication is not surprising, since the swarm was associated with observed volcanic eruptions.

There is now strong evidence from experiments on microfracturing of rocks ( ${ }^{2 i j}$ and from earthquakes (11,34) that the coefficient $b$ is inversely correlated with the stress conditions. During several earthquake sequences in New Zealand and in California, and in some swarms in other regions, $b$ has been found to vary. This has been interpreted in terms of stress changes taking place during the sequences $(\mathbf{1 0 , 1 2 . 3 7})$.

A very convenient technique, applying the maximum likelihood method to a fixed number of earthquakes $\Delta N$, was used in order to 
find the variation of $b$ during this swarm. The procedure establishes a constant statistical uncertainty and a variable time-window. The results are shown at the bottom of Fig. 12. Values of $b$ were calculated for sets of 100 shocks, spaced at intervals of 25 shocks, and assigner to the mean of each time interval involver.

During the swarm, $b$ decreased from about 1.8 , the value characteristic for the whole sequence, at the beginning of the swarm, to 1.1 in the mirldle, when the largest shock occurrer. It then starter to increase sharply, reaching a value of 2.5 during the final periorl of the activity. Events interpreter as volcanic eruptions took place exclusively after the value 2.2 was reacher.

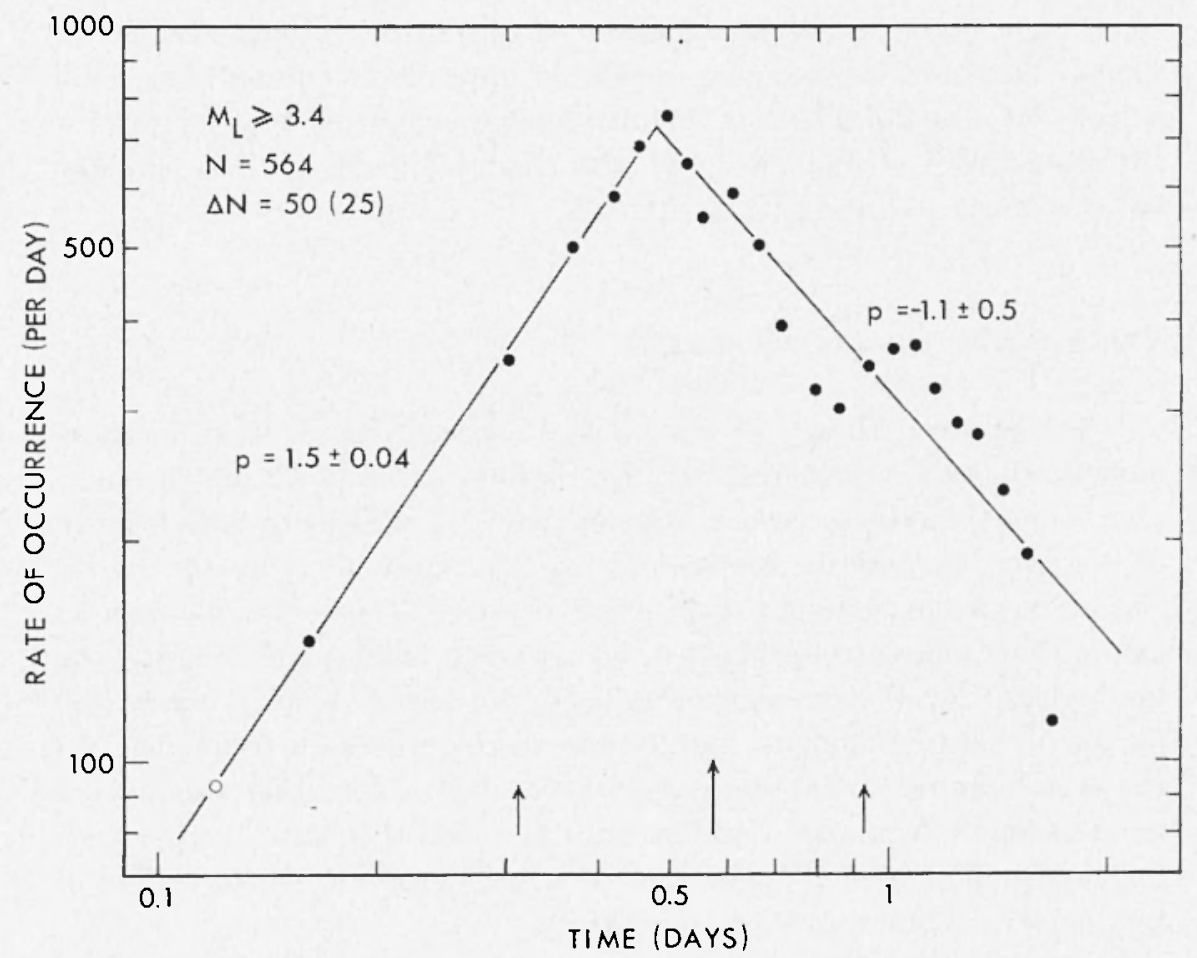

Fig. 9 - Rate of oceurrence versus time, for earthquakes of magnitude $M_{L} \geqslant 3.4$, during two stages of the swarm. Values are calculated for sets of 50 shocks, spaced at intervals of 25 shocks, and assimned to the mean of each time interval involved. The first value, marked by an open circle, is calculated for 25 shocks. The smoothed trend is shown by straight lines.

The arrows mark the time of occurrence of earthquakes of $M_{L}>4.5$. 
The difference between the highest and the lowest values of $b$ is statistically significant at the $99 \%$ confidence level when tested by the $F$-test $\left(^{32}\right)$. The pattern of $b$ changes suggests that the stress was increasing until the release of the largest shocks, and that it then rlecreaserl until stability was achieved and the swarm enderl. This pattern is of type 3, established from the sturly of several earthquake swarms (12)

The peak of the swarm activity, as expressed in the rate of earthquake occurrence (Fig. 9), and the lowest value of 6 (Fig. 12) do not coincide precisely; they are, however, very close to one another. It is not clear whether the time lag observed has a physical significance or whether it results simply from the statistical processing of the data. In any case, high values of the rate of occurrence correspond to low values of $b$, when stress was presumably high. The result is not unexpecterl, since high stress would be expected to produce a larger number of shocks, but the conclusions are precisely opposite to those drawn from a study of aftershocks (11). This discrepancy confirms once again that the mechanism of generation of aftershocks and that of earthquake swarms must be inherently different.

\section{VARIATION OF SOURCE PROPERTIES}

The spectral theory of earthquake sources, baserl on dislocation models, allows two principal parameters to be estimated from the spectrum of earthquake waves: seismic moment $M_{0}$, measuring the strength of a source, and source dimension, usually represented by the raulius $r$ of an equivalent circular dislocation surface. These two parameters define other source properties: $\bar{u}$, the average displacement across the fault plane; $\Delta \sigma$, the stress-drop; and $z_{s}$, the seismic energy, when it is assumed that the spectral amplitudes decrease at high frequencies in the same manner for all earthquakes $(2,3,5,6,19,23)$. A further assumption is often male in practical applications of spectral theory; the decrease in amplitude at high frequencies is inversely proportional to square of frequency, as first proposed by $\mathrm{Aki}\left({ }^{3}\right)$.

However, spectral analysis of recorded seismic phases is a very complex technique and cannot easily be applied on a large scale. A more direct approach is possible. Local magnitude $M_{L}$ is an additional spectral parameter of the seismic source, complementing seismic moment and source dimension $\left({ }^{23}\right)$. For source radii greater than about $0.5 \mathrm{~km}$ the values of moment and magnitude $M_{L}$ are sufficient to define 
Brune's (5) far-field spectrum (13). In other words, source raulius can be specified from the seismic moment and magnitude $M_{L}$ alone, and other source properties can therefore also be obtained.

The long-period parameter $A R$, defined by Brune of al $\left({ }^{i}\right)$, has been userl to estimate the seismic moment, and it las been proved that this method is sufficiently effective, and at the same time it is very simple to employ $(29.35,36)$.

The Ifiamalu station of the WWSSN is situated at a distance of about $250 \mathrm{~km}$ from the centre of the swarm activity. The long-period Press-Ewing seismographs have the rather low magnification of 750 , because of a persistently high noise level, and therefore only the larger

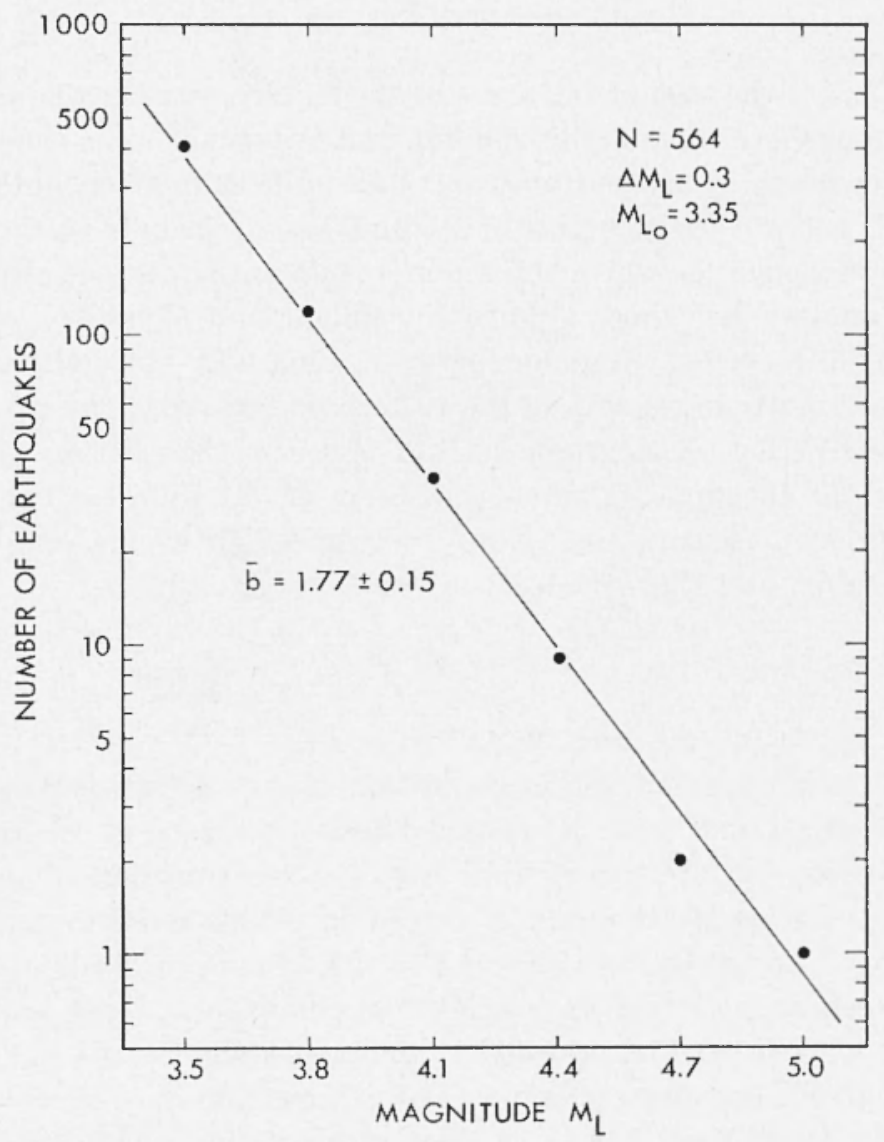

Fig. 10 - Number of earthquakes of a given magnitude for the whole swarm. 
earthquakes of the swarm were arlequately recorderl. The paper speed of recording for these instruments is $15 \mathrm{~mm} / \mathrm{minute}$.

The long-period parameter $A R$, measuring the excitation of surface waves, is the sum of the areas under the envelope of the surface waves recorderl on all three components of a Press-Ewing seismograph( $\left.{ }^{7}\right)$. Only earthquakes with $A R \geqslant 1 \mathrm{~cm}^{2}$, as recorded at $A$ fiamalu, were used in this study. Nltogether, 118 events were found to fulfil this criterion. These values of $A R$, reducerl to a common distance of $250 \mathrm{~km}$, are listerl in Table I, together with their respective values of $M_{L}$, which are given in brackets when estimaterl from the amplitudes of $T$ phases. The more ambiguous values of $A R$ are also given in brackets.

$A R$ is proportional to the seismic moment $\left({ }^{35}\right)$ :

$$
\log M_{0}=\log A R_{250}+C
$$

where $A R_{\mathbf{2 5 0}}$ is the sum of the areas of the surface-wave envelopes normalized to a source distance of $250 \mathrm{~km}$, and $C$ depends upon the instrumental constants. This constant can be found from independent estimates of $M_{0}$ and $A R$ for a number of earthquakes. The only earthquakes in northern Tonga for which seismic moments are alrealy known from spectral analysis are those studied by Molnar and Wyss (22). Out of seven possible events, occurring between 1963 and 1968, either very close to or exactly in the area of the 1973 swarm activity, two overloared the long-period seismographs at $\triangle \mathrm{FI}$ and one, the earliest, was recorderl by the instruments when they were set at different constants from those at present in use. Thus, records of four events were found to be suitable, and they yielded the value

$$
C=22.80
$$

where $A R_{250}$ is in $\mathrm{cm}^{2}$, and $H_{o}$ in dyne $\mathrm{cm}$.

This value is remarkably close to that obtainerl from earthquakes in New Zealand and in the Kermarlec Islands, recorded at Wellington, where the long-period seismographs have the same magnification as at AFI but twice the paper-speed of recording. This requires a correction of $+0.3(\log 2)$ to the value of $C=22.4$ found in Wellington $\left({ }^{13}\right)$.

Diflerences in surface-wave excitation due to focal depth and focal mechanism have been disregarded. The precise depths are unknown, although all events were certainly shallow. Nor can the focal mechanisms be reliably determined, but the narrow range of azimuths between the position of the selected shorks and AFI (see Fig. 1) makes it highly 
improbable that the surface-waves would have been seriously affected by small variations in focal mechanism during the sequence.

It is convenient to use "normalized seismic moment $\boldsymbol{H}^{\prime}{ }^{\prime}$ ", insteal of seismic moment itself, since this is equal to the magnitude $\boldsymbol{I}_{L}$, for sources of radius smaller than about $0.5 \mathrm{~km}\left({ }^{13}\right)$

$$
\boldsymbol{M}_{o}^{\prime}=\log \boldsymbol{M}_{0}-17.16 .
$$

From [4] and [5]

$$
\boldsymbol{I}_{0}^{\prime}=\log A R_{250}+\tilde{\mathbf{5}} .64
$$

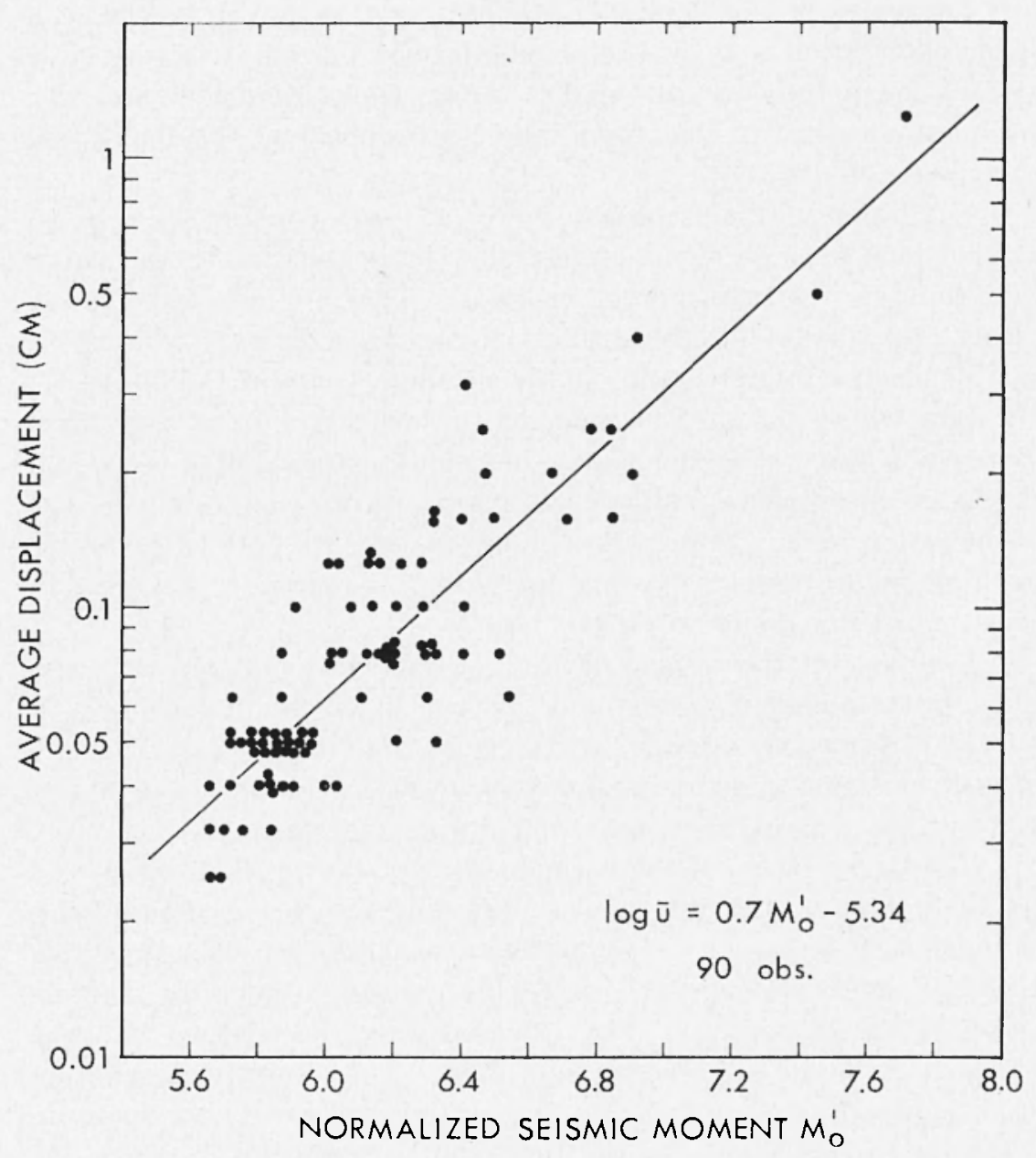

Fig. 11 - Average displacement versus normalized seismic moment. 
The most suitable parameter to describe differences in source properties in various regions, or locally in time, is the average displacement $\left.{ }^{13}\right)$. Values of the average displacement $u$ were accordingly calculated from $\boldsymbol{H}^{\prime}{ }_{0}$ and $\boldsymbol{H}_{L}$. They are shown as a function of $\boldsymbol{I}^{\prime}{ }_{0}$ in Fig. 11, and are approximated by

$$
\log u=0.7 M_{o}^{\prime}-5.34
$$

where $u$ is in $\mathrm{cm}$. Values of $M_{L}$ used for the approximation are only those based on the amplitude of body-waves: those based on $T$ phases have not been userl.

The value of the slope $0.7 \pm 0.38$ (the standard deviation of a single observation is $\mu_{o}= \pm 0.14$ ) obtained in this study is very close to that found from 22 earthquakes in the Tonga-Kermadec arc, and is almost identical to that from the 66 aftershocks of the Inangahua earthquake of $1968\left({ }^{13}\right)$.

The value of displacement, however, corresponding to a given seismic moment, retermined by formula [7], are about 10 times smaller than those for the Inangahua aftershocks. They are in fact the lowest values found so far in any legion, being comparable only to those in the Mendocino fracture zone off the northern coast of California (13).

Low values of displacement mean low stress-drops and large source dimensions of earthquakes. Anomalously large rarlii of individual shocks in the sequence reinforce conclusions drawn concerning the size of the swarm zone. These values imply very low strength of the source material, inclicating pre-existing faults and fractures in the area; in short, a zone of major weakness.

Residuals of the displacement, the differences between the logarithm of the observed value $u$ and that calculated from formula [7], in all 118 earthquakes, are displayed against time in Fig. 12. They represent variation of source parameters, reflecting properties of source material, as a local effect occurring during the swarm.

The largest vilue of the normalized displacement is about five to six times greater than the smallest, the difference being almost twice as much as that during the Inangahua aftershocks (13). The time variation of the displacement shows an inverse correlation with the variation of the coefficient $b$ (Fig. 12), and direct correlation with the variation of the rate of occurrence (Fig. 9). The respective correlation coefficients are -0.85 and 0.78 . The pattern has clearly the opposite character to that found for the Inangahua aftershocks, in which the variation of source properties displayed a direct correlation with the coefficient $b$. 


\section{Voldaxid ERUP'IONS}

To active volcano was previously known in the Curaçoa Reef area. Richard ( ${ }^{24}$ ) has compiled a catalogue of activity in the region and places the nearest active centre at Niuafo'ou (Tin Can Island), more than $200 \mathrm{~km}$ to the west.

The first observed volcanic activity in the present sequence was seen from Tafahi Island (Fig. 2) during the morning of Friday $13 \mathrm{July}$ (local time), sometime between 17 and 23 hours, L.T., on 12 July*, when a rising cloud column was noticer to the north-northeast ( $T$. Simkin, pers. comm.). This was during the latter part of the swarm, at least 9 hours after the event interpreter as the main eruption. On the afternoon of the next day, at about $0+$ hours L.T. on $14 \mathrm{July}$, the eruption was seen from the air in a position estimater as $35 \mathrm{~km}$ northwest of Curaçoa Reef (Fig. 2) (27,28). It this time a white steam cloud extended to an altitude of about $5 \mathrm{~km}$, and the surface of the sea over an irregular ellipse, dimensions estimated as $12 \pm+\mathrm{km}$ by $8+3 \mathrm{~km}$, was covered with pumice. The ermption site was reported to be "boiling", and Simkin and Onyeagocha interpret this as indicating that pumice was still being actively supplice to the surface.

On Monday $16 \mathrm{July}$ (local date) Mr J. C. Riechelmann flew over the area on a charter flight from Nukualofa, and located the eruption point about $3 \mathrm{~km}$ south-southeast of Curaçoa Reef (T. Simkin, pers. comm.). This position agrees well with the direction reported from Tafahi, but rather poorly with the aerial sighting on 14 July. There are no other reports of sightings of the eruption, other than two further observations from Tafahi, of a vapour cloud on Sunday 15 July (local (late), and of a red glow seen in the clouds during the night of 15-16 July, both in the same direction as the previous observation. The pumice raft formed by the eruption was entered by the ship "Union Sonth Pacific" on $25 \mathrm{July}$, in a position some $200 \mathrm{~km}$ west of Curaçoa Reef. Samples were taken which, analyserl, were found to be dacitic, with a silica content of $68 \%$ (P.R.T. Browne, pers. comm.).

Particular events of the swarm were irlentified as volcanic eruptions on the basis of their large T-wave amplitules on the Wake Island hychophone records compared with body wave magnitudes, and on the character of the $T$-wave arrivals at the Wake hydrophones. The

(*) Tonga local time is 13 hours ahead of Lniversal Time. 


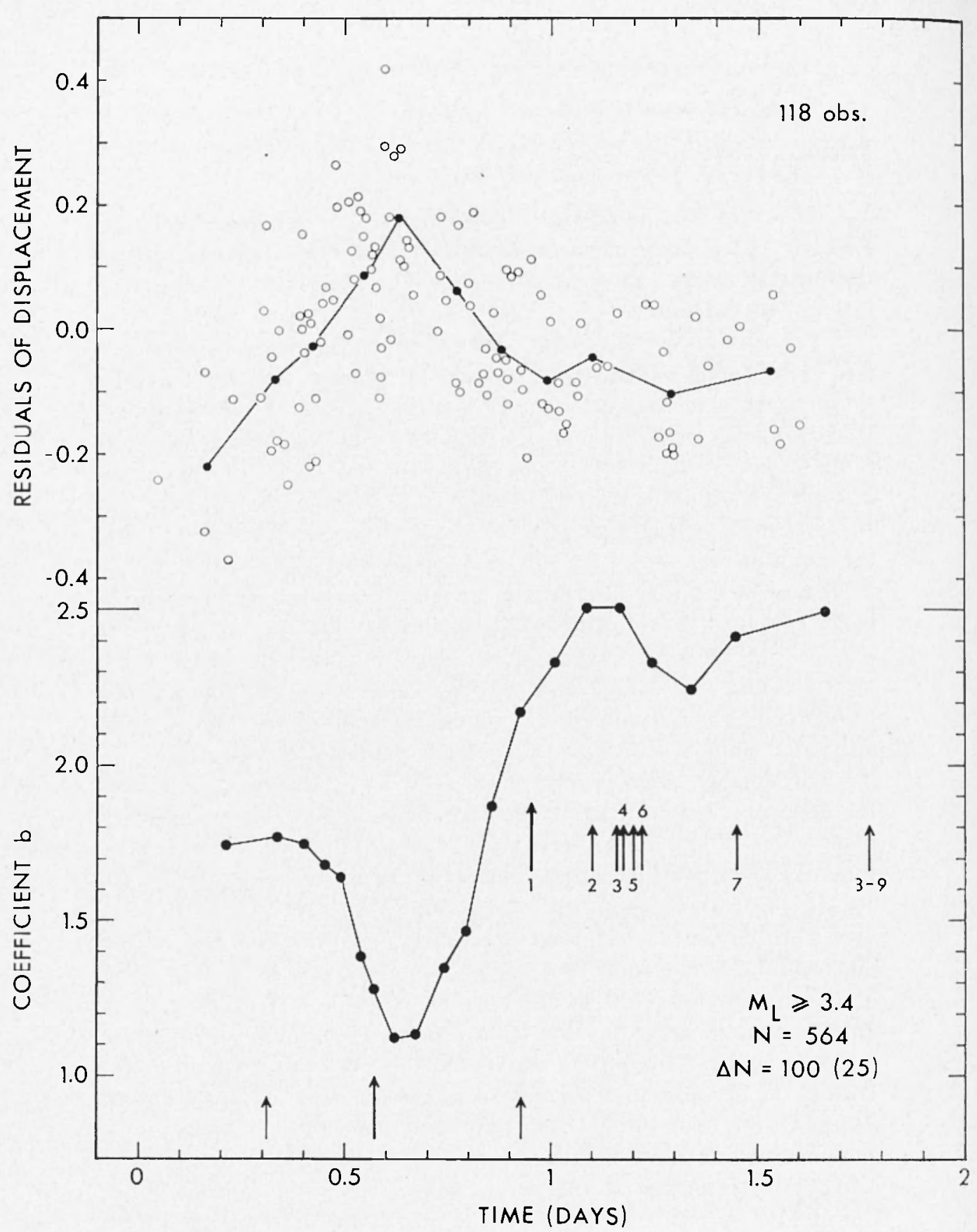

Fir. 12 - Variation of the coefficient $b$ and of the displacement residuals during the swarm. Values of $b$ are calculated for sets of 100 shocks, spaced at intervals of 25 shocks, and assigned to the mean of each time interval involved. Mean values of the displacement residuals are represented by filled circles and aetual values from consecutive earthquakes by open circles. The unnumbered arrows show the time of occurence of earthquakes of $H_{L}>4.5$, and the numbered arrows the voleanic eruptions listed in Table II.

The largest eruption is shown with a longer arow. 
large events thus interpreted are listed in Table II. Variation in differences between $T$-wave arrivals at various pairs of stations among Wake, AFT, NUE and RAR, give an inclication of the source of volcanic origins relative to the main event. Differences betwen $T$-wave arrivals suggest that eruptions Nos. 1 to 7 took place at or near a single point, and eruptions Nos. 8 to 9 near a second point, which appears to have been close to the epicentre of the principal earthquake.

If the main eruption is assigned to the position given by Riechelmann's observation as a few kilometres south-southeast of Curaçoa Reef, it seems likely that eruptions Nos. 8 and 9 took place at the point observed from the air about $35 \mathrm{~km}$ northwest of the reef.

Pumice was first discovered on the beaches of Tafahi on $1+$ or 15 July. Supposing a clrift rate of the order of $15 \mathrm{~km} / \mathrm{dlay}$, about half the maximum rate quoted by Simkin and Onyeagocha $\left(^{2 \pi}\right)$, the distance between Curaçoa Reef and Tafahi would have been covered in about two and a half clays. This is consistent with an origin on 12 July between about 05 and 23 hours U.T., which is the period dluring which eruptions 1 to 7 took place.

The scarcity of borly waves, anomalously large $T$ phases, the fact that the Wake hydrophone records were overloaded by the larger eruptions, and consequent uncertainties in the true magnitudes of many of the events, preclucle the possibility of assigning reliable energy figures to the individual eruptions. However, the pumice raft is estimated by Simkin and Onyeagocha (27) to have had a volume, freshly ejected, of not less than $0.06 \mathrm{~km}^{3}$. Following Hedervari $\left({ }^{15}\right)$, this yields an eruption magnitude $M_{e}$ of 8.0 , and a thermal energy of eruption $E_{t h}$ of about $6 \times 10^{16} \mathrm{~J}$ for the whole series of eruptions. The hyclro-acoustic and seismic data show that by far the greater part of this energy was liberated in a single eruption, the first in the series.

Observed $b$ variations define a pattern with important implications for volcanology. The first, and principal, eruption took place well after the reversal in the trend of $b$ (coinciding approximately with the time of the largest earthquake in the series), when its value had alrearly reacherl the very high level of 2.2 (Fig. 12). It is inferred that dluring this stage stress was declining markedly and had dropperl, by the time of the first eruption, to a level considerably lower than that which existed at the time when the swarm began.

$A$ plausible explanation of the observations is that increasing stress, due presumably to increased magmatic gas pressure, or to rise 
of magma, or to a combination of both causes, finally overcame an obstruction, giving rise, as it clicl so, to the largest earthquakes in the sequence. This stage was then followed by a period of intrusion of magma under declining stress conditions. It is notable that the largest earthquake (Fig. 2) took place in an area away from the main grouping of eruptions.

After the final pair of eruptions in the sequence occurred, well away from the source of the principal eruption, and within a few minutes of ach other, seismic activity rapiolly came to an end, less than a dozen eathouakes being recorded during the following eight houl's.

Conchenions

(1) This earthquake swarm, which occurred at the extreme northern end of the Tonga-Kermadec are, was characterized by an unusually large area of activity for the relatively small earthquakes involved (the largest being of $\Pi_{L}=5.1$ ).

(2) The swarm was followed by a substantial submarine eruption, which produced not less than $0.06 \mathrm{~km}^{3}$ of dacitic pumice, indicating an eruption magnitude of 8.0, and a thermal energy output of the order of $6 \times 10^{16} \mathrm{~J}$. Antuptions probably took place at two localities 35) to $40 \mathrm{~km}$ apurt.

(3) The changes of rate of earthquake occurrence dhuing the swarm showed two distinct stages, one similar to that in a foreshock sequence, and the other like that in an aftershock sequence, with the largest shocks occurring in the middle of the swarm. The foreshock stage was much more vigorous than that precering a normal large earthquake. The decay coefficient $p$ in the second stage was close to -1 , a value characteristic of aftershock sequences.

(4) The swarm was characterized by a very high average value of the coefficient $b$ (about 1.8), which tends to confirm its volcanic origin.

(5) The frequency-magnitude relationship varied during the swarm. The coefficient $b$ decreased from 1.8 at the begimning to 1.1 in the micldle of the sequence, when the largest shocks occurred, and then started 
to increase shapply, reaching the very high value of 2.5 during the final stage of the activity. Events interpreted as volcanic eruptions took place exclusively in the later stages, after $b$ had reached a level of about 2.2. If the changes in $b$ are related to the stress changes, the variation in $b$ suggests an initial increase in stress until the occurrence of the largest shocks, followed by a decrease until stability was reached, the swarm then ceasing. Low values of $b$ coincide with high values of rate of occurrence, showing that it was high stress conditions that produced the larger number of shocks.

(6) The souree dimensions of individual earthquakes were unusually large and the average displacements and stress dops musually low. These values of the source parameters imply very low strength for the source material which is interpreted in terms of pre-existing faults and fractures in the area; in short, a zone of major weakness.

(7) Changes in the residuals of the average displacement show that variation of sonre properties took place during the swarm. The displacement increased from the beginning of the swarm until the occurrence of the largest shocks, and then decreased during the second stage of the sequence. The time variation of the displacement shows an inverse correlation with the variation of the coefficient $b$, and a direct correlation with the variation of the rate of occurrence. Larger values of the displacement (or small source size and high stress drop) imply a higher strength in the source material, while low values of $b$ suggest high stresses in the focal area, and conversely. Higher strength of the material and comparatively high stress resulted in the generation of a large number of eathquakes, including the principal events, while lower strength of material and correspondingly low stress produced earthquakes of smaller magniturle, in decreasing number, together with voleanic eruptions. The correlation between source properties and $b$ values during the swarm is of opposite character to that found for the Tuangahua aftershock sequence of $1968\left({ }^{13}\right)$. This strongly suggests a very different mechanism of generation for earthquake swarms and aftershocks. The relationship between stress field and strength of material is crucial in the interpretation of this problem. It appears that during this particular earthquake swam the dominant role in the generation of earthquakes was played by a highly concentrated stress field of volcanic origin lather than by changes in strength of generally weak material. Low stresses during the second stage of the swarm resulted in the occurence of a decreasing number of smaller 
shocks, even when the strength of the material was lower than during the peak of the swarm activity. In view of the occurrence of a volcanic eruption it seems likely that the changing source properties reflect the upward migration or intrusion of magma into higher, and weaker, levels in the crust.

(8) The inferred stress variations have important implications for volcanology. The eruptions took place under declining stress conditions, when stress had reacher a level considerably lower than that which existerl when the sequence of earthquakes began. The principal earthquakes, on the other hand, marked the end of a period of increasing stress. It is concluded that they took place when an obstruction of some kind failed under conditions of widespread magmatic intrusion. After the principal earthquakes, intrusion contimued without encountering serious obstacles, culminating in a large eruption.

(9) $T$ waves were generated by earthquakes in the swarm, and were the strongest phases recorded at stations situated on the oceanic side of the Tonga Trench. They were not recorded at stations located on the continental side of the are. This, together with the fact that $T$ phases arrived much earlier than expected at recording stations to the southeast, suggests that they originated within the Tonga Trench itself.

\section{ACKNOWLEDGMENTS}

It is with particular thanks that the authors acknowledge the help of Mr R. H. Johnson, of the Hawaii Institute of Geophysics, who most generously supplied records from the hydrophones near Wake Island. Similar thanks are due to $\mathrm{Mr}$ J. Ni of Cornell University, for providing records from the seismograph stations at VUN and TEK, and to Dr. T. Simkin of the Smithsonian Institution, for a wealth of information and assistance. Thanks are also due to the Master, Captain J.A.F. Jenkins, and crew of the "Union South Pacific", Captain J. F. Collins of the Union Steam Ship Co. of New Zealand Istd., Dr P. R. I. Browne, Dr C. P. Wood, and Mr I). Clyma of the New Zealand Geological Survey, Dr T. J. Cullen of the New Zealand Oceanographic Institute, Professor A. C. Kibblewhite of Auckland University, the U.S. Naval Attache in Wellington, $\mathrm{Mr} \mathrm{I}$. $\mathrm{N}$. Hart of Dynalectron Corporation, Hawaii, Mr D. F. Graf of the Government of American Samoa, and to station 
operators of Afiamalu, Nine and Rarotonga. The authors also acknowledge the helpful alvice of a number of their colleagues in Geophysics Division of I).S.I.R., particularly Dr R. I). Adams, who initiated this sturly, Mr G. A. Eiby, Dr T. Hatherton, and Dr P. W. Rorlgers.

\section{REFERENCES}

(1) AKI K., 1965. - Marimum lilielihood estimate of $b$ in the formula $\log N^{+}=a-b . M$ and its confidence limils. "Bull. Earthq. Res. Inst.", 43, pl. $237 \cdot 239$.

$\left.{ }^{2}\right)$ AкI K., 1966. - Generation and propagation of G uaves from the Niigate earthquake of June 16, 1964, 2. Estimation of earthquake moment, released energy, and_stress-strain drop from. G wave spectrum. "Bull. Earthq. Res. Inst." 44, pp. 73-88.

(3) Aki K., 1967. - Scaling law of seismic spectrum. "J. Geophys. Res.", 72, Pp. $1217-1231$.

(1) BАти M. and Snamid M., 1971. - T-phases from Atlantic earlhquales. "Pure Appl. Geopliys.", 92 (9), pp. 74-114.

(5) BRUNe J. N., 1970. - T'ectonic stress and spectra of seismic shear waves from earthquakes. "J. Geophys. Res.", 75, pp. 4997-5009.

(') Bruxe J. N., 1971. - Correction. "J. Geophys. Res.”. 76, p. 5002.

(7) Brune J. N., Espinosa A. and OLIVER J., 1963. - Relative excilation of surface waves by earthqualies and underground explosions in the California-Nevada region. "J. Geophys. Res.", 68, p1). 3501-3513.

(8) Everndex J. F., 1970. - T-phase dala on Kamehatha-fiurils earlhquales. "Bull. Seism. Soc. Am.", 60, p1. $1061-1076$.

$\left.{ }^{(}\right)$Gibowicz S. J., 1972. - Amplitude of P waves recorded at New Zealand stations from shallow earlhquales at less than $30^{\circ}$. New Zealand J. Geol. Geophys.", 15, p1. 336-359.

(10) Ginowicz S. J., 1973a. - Fariation of the frequency-magnitude relation. during earthquale sequences in New Zealand. "Bull. Scism. Soc. Am.", 63, pp. 517.528 .

(11) Gibowicz S. J., 19731). - Stress drop and aftershocks. "Bull. Seism. Soc. An. “, 63, pp. 1433-1446.

(12) Gibowicz S. J., 1973c. - Pallerns of earthquake suarm. activily. "Ann. Geofis.", 26, 4, pp. 637-658.

(13) Gibowicz S.J., 1975. - Tariation of source properties: the Inangahua, Seu Zealand, aflershocks of 1968 . "Bull. Seism. Soc. Am.", 65, 1, in press.

(14) Guteniber B. and Richter (C. F., 1954. - Seismicity of the Earlh and Associaled Phenomena. Princeton Vniv. Press, Princeton, p. 310.

(15) Hedervari P., 1968. - Tolcanophysical incestigations on the energetics of the Minoan eruption of coleano Santorin. "Bull. Volcan", 32, pl. 439-461. 
(16) Isacks 13. I., SYkes L. R. and OLIYRR J., 1969. - Foeal mechamism. of deep and shallow earlhquales in the Tonga-Kermadec region and the lectonics of island ares. "Bull. Grool. Soc. Am.", 80, pp. 14+3-1470.

(17) Jomsox R. H., 1966. - Routine localion of T-phase sources in the Pacific. "Bull. Seism. Soc. Am.", 56, pr. 109-118.

${ }^{(18)}$ Jomson T. and Mowsar P., 1972. - Foeal mechanisms and plale leclomies of the Soulhwest Pacific. "J. Geophyss. Res.", 77, pl. 5000-5032.

(19) KEYLIs-Borok V. I., 1959. - An estimation of the displacement in an earlhqualie source and of source dimensions. "Ann. Geofis.", 12, 11. 205. 214.

${ }^{(20)}$ LIEBERMAx R. (. and Poneroy P. W., 1970. - Source dimensions of small earthqualies as determined from size of the allershock zone. "Bull. Seism. Soc. Am.", 60, pp. 879-890.

(21) Mogi K., 1963. - Some discussions of aflershocks, foreshocks, and earthquake swarms - The frachere of a semi-infinite body cansed by an inner stress origin and its relation to the earlhquale phenomena (3ral papar). "Bull. Earthq. Res. Inst.", 41, 1). 615-658.

(22) Motida P' and WYss M., 1972. - Moments, souree dimensions and stress drops of shallow-focus earlhqualies in the Tonga-Kermadec Are. "Phys. Earth Planet. Inter.", 6, pl. 263-278.

(23) RaxbaLL M. J., 1973. - The spectral theory of seismie sources. "Bull, Seism. Soc. Am.", 63, 11). 1133-1144.

(2.) Riciand J. J., 1962. - Calalogue of the active rolcanoes and solfatara fields of Fermadec, Tonga and Samoa, Calalogue of the aclive volcanoes of the rorld including solfalare fields. Part 13, "Intern. Assoc. Volcan.", Rome, 38.

(25) Richter (. F., 1935. - In instrumenlal earlhqualie magnilude scale. "Bull. Scism. Soc. Am.", 25, p). 1-32.

(2n) Scirot.z C. II., I968. - The frequency-magnitude relation of mierofrachuring in rock and its relation to earthqualies. "Bull. Scism. Soc. Am.", 58, pl. 399-415.

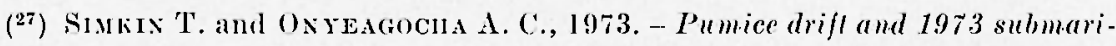
ne eruplion, North Tonga Islands. "Smithsonian Contrib. Earth. Scien.", in press.

$\left.{ }^{28}\right)$ Smitisonax Ixstitutios, 1973. - Curaçoa Reef submarine voleamic activity. Event Notification Report, Conter for Short-lived Phenomena, No. 1679, 19 July.

(29) THatcher W., 1972. - Regional varialions of seismic souree parameters in the Norlhern Raja Califormia area. "J. Geophys. Res.", 77, p1) 1549-1565.

(3i) I'Tsu 'T., 1961. - A slatistical shudy on the oecurrence of aftershocks. "Geophys. Mag.", 30, pp. 521-605.

(3) Lrsu T., 1965. - 1 melhod for determining the ralue of $b$ in a formult $\log n=a-b .1$ showing the magnilude-jrequency relalion for enthquakes. "Geophys. Bull. Hokkailo Univ.", 13, pp. 99-103.

(32) U'Tsu T., 1966. - . A stalistical significance test of the difference in b-ralue between the earthqualie groups. "J. Phys. Earth." 14 (2), pl. 37-40. 
(23) Warrex N. W. and Latmas G. V., 1970. - An experimental study of thermally induced microfracturing and its relation to volcanic seismicily. "J. Geophys. Res.", 75, pl). 4455-4464.

${ }^{(34)}$ WYss MI., 1973. - Towards a physical understanding of the earthquake frequency distribution. "Grophys. J. Roy. Astr. Soe.", 31. p1. 341-359.

${ }^{(35)}$ Wrss II. and Brune J. N., 1968. - Seismic moment, stress, and source dimensions for earthquales in the Calijornia-Nevada region. "J. Geophys. Res.", 73, Il). 4681.4694.

${ }^{(36)}$ Wrss II, and BRUNe J. X., 1971. - Regional varialions of source properties in southern California estimated from the ratio of short-to long-period amplitudes. "Bull. Seism. Soc. Am.", 61, pl. 1153-1167.

${ }^{\left({ }^{37}\right)}$ Wrss II. and Les W. H. K., 1973. - Time variations of the average earthquake magnitude in central California. Proc. Conf. Tect. Probl. San Andreas Fault System, Stanford Univ., "Geol. Scien.", 13, pl. 24-42. 